Canadian Science Publishing

Canadian Journal of Earth Sciences Revue canadienne des sciences de la Terre

\title{
Geophysical models of the Montresor metasedimentary belt and its environs, central Nunavut, Canada
}

\begin{tabular}{|r|l|}
\hline Journal: & Canadian Journal of Earth Sciences \\
\hline Manuscript ID: & cjes-2015-0008.R1 \\
\hline Danuscript Type: & Article \\
\hline Complete List of Authors: & $\begin{array}{l}\text { Tschirhart, Victoria; Geological Survey of Canada, } \\
\text { Percival, John A.; Geological Survey of Canada, ; } \\
\text { Jefferson, Charlie W.; Geological Survey of Canada, Natural Resources } \\
\text { Canada }\end{array}$ \\
\hline Keyword: & Montresor belt, magnetics, gravity, modelling \\
\hline \multicolumn{2}{|c}{} \\
\hline
\end{tabular}


Geophysical models of the Montresor metasedimentary belt and its environs, central Nunavut, Canada

Tschirhart, V. ${ }^{1}$, Percival, J.A. ${ }^{1}$ and Jefferson, C.W. ${ }^{1}$

1. Geological Survey of Canada, 615 Booth St., Ottawa, Ontario, K1A 0E9. 


\begin{abstract}
Recent identification of hydrothermally altered rocks and breccia in the underexplored Montresor belt of Paleoproterozoic metasedimentary rocks suggests the possible presence of undiscovered mineralization. This study examines potential field data from the region with the goal of identifying subsurface features that could be associated with or serve as vectors to mineralization (subsurface alteration zones, faulting and/or igneous intrusions). Gravity data were used to model regional and local geological features using known geology and physical properties from the study area and environs as constraints, and documents dense intrusive bodies underlying the Paleoproterozoic sequences. Maps of transformed apparent magnetic susceptibility values outline corridors of weak magnetization that correspond to observed zones of non-magnetic breccia and epidote-hematite-quartz alteration. Imputing the apparent susceptibility and rock property information into a magnetic forward model defines the geometry of this alteration zone, which is best explained as a northerly dipping non-magnetic or demagnetized, metasomatized intrusive sheet. The presence of previously undocumented igneous intrusions, their association with demagnetized hydrothermal breccia, and the continuity of the demagnetized zone suggests additional prospective areas within the region. This geologicalgeophysical framework for the nature and geometry of the Montresor belt and its surrounds highlights the importance of integrated modelling for areas with limited data.
\end{abstract}

Key words: Montresor belt, magnetics, gravity, modelling 


\section{Introduction}

Mineral exploration in the Western Churchill region is in its infancy, owing to remoteness, geological complexity and lack of a robust geoscience knowledge base (Pehrsson et al. 2013a, b). This is particularly true of the Rae province, that experienced variable reworking by regional tectonic events at 2.45-2.30 Ga (Arrowsmith Orogeny), 2.03-1.90 Ga (TaltsonThelon orogeny) and 1.90-1.78 Ga (Hudsonian orogeny) (Berman 2010; Berman et al. 2013), each of which could have introduced magmas, fluids and structures conducive to the formation of mineral deposits. This study addresses the Montresor belt of strata deposited ca. 2.3-1.9 Ga that is part of the Rae cover sequence (Rainbird et al. 2010), along with the Archean substrate of the belt.

Located $250 \mathrm{~km}$ north of the community of Baker Lake, Nunavut, the Montresor belt is a narrow syncline of Paleoproterozoic metasedimentary rocks underlain by Archean basement (Fig. 1). Prior to the 2014 field season, only two reconnaissance studies had been conducted, the first being systematic mapping (Frisch and Patterson 1983; Frisch 2000) that defined the basic geology and structure. The belt was revisited in 2012 as part of a reconnaissance sampling program to assess the level of outcrop exposure for potential future mapping and economic evaluation. One of the samples collected in 2012 identified a hydrothermal breccia with elevated levels of $\mathrm{Cu}, \mathrm{Ag}$ and $\mathrm{Au}$ (Percival et al. 2015). This style of mineralization had not been recognized elsewhere in the region and warranted further study to determine its nature and extent. Fieldwork in 2014 included mapping of the $500 \mathrm{~m}$ thick, stratabound breccia zone with a strike length of at least $4 \mathrm{~km}$ that includes breccia and intensely altered igneous rocks with sparsely preserved primary textures. The association between the igneous rocks and hydrothermal breccia suggests a link between magmatism, hydrothermal alteration and 
deformation that could have generated a variety of mineral deposit types such as mesothermal to epithermal precious and/or rare metals, base metal veins, breccia-hosted, skarns or mantos (e.g. Kelley and Ludington 2002).

An assessment of regional gravity data (12-15 km station spacing) identified a positive anomaly over the breccia zone. Only one station is located on the breccia zone, however the gravity high is at the north end of a $20 \mathrm{~km}$ long anomaly is defined by three stations extending south to the Amer Mylonite Zone (H3, Fig. 2). A visit to outcrops in the vicinity of the gravity station documented breccia and siltstone units with measured densities around $2.70 \mathrm{~g} / \mathrm{cc}$ (Table 1) in an area with flat topography, implying that the anomaly is caused by a denser body at depth. A detailed gravity transect, Profile 3, conducted in the summer of 2014 characterized this anomaly in more detail.

The present paper commences with an examination of the regional characteristics of the gravity field and their geological significance, followed by a description and interpretation of the detailed gravity transect. An established method to discern more information from the apparent susceptibility maps is subsequently applied to high-resolution aeromagnetic data for the region, followed by detailed 2D forward modelling of magnetic anomalies associated with the syncline.

\section{Geological setting}

The Rae craton of the western Churchill Province of the Canadian Shield is an Archean terrane with a complex history of Paleoproterozoic sedimentation, magmatism and tectonothermal reworking (Berman et al. 2013). A widespread, dominantly sedimentary package with minor plateau basalt, the Rae cover sequence (Rainbird et al. 2010), is discontinuously preserved across the craton in belts including the Amer, Ketyet River and Montresor. The $80 \mathrm{~km}$ 
long by $5 \mathrm{~km}$ wide Montresor belt, the focus of this study, consists of two components: 1) an upper, weakly deformed and metamorphosed sedimentary package preserved in the axis of a narrow open syncline; and 2) a footwall complex made up of imbricate panels of metasedimentary schist and granitoid basement rocks. Footwall schist units comprising quartzite, carbonate and pelite at middle amphibolite grade are in D1 tectonic contact with the underlying augen granitic gneiss. The schist units strongly resemble regional Ps 1 and Ps2 units of the Rae cover sequence as defined by Rainbird et al. (2010) and Pehrsson et al. (2013a), whereas the gently folded, greenschist-facies upper sequence may correlate with regional Ps3 or Ps4 strata. Because the upper sedimentary package lacks D1 structures present in the Ps3 portion of the Amer Belt, it may be a fine-grained facies of Ps4, however the sedimentary package contains prominent magnetic marker units that strongly resemble those of Ps3 in the Amer belt $50 \mathrm{~km}$ to the south. In the Montresor belt the magnetic units appear on aeromagnetic maps (Miles and Oneschuk 2013) as northeast- southwest-trending concentric ellipses outlining open, doubly plunging synclines (Fig. 3).

On the southeast flank of the Montresor belt north of the Back River a seemingly stratabound zone of breccia and intense hydrothermal alteration is hosted within a magnetic siltstone unit (Percival et al. 2015). Mapped over a strike length of $4 \mathrm{~km}$, the zone is marked by a pronounced negative aeromagnetic anomaly that continues beyond the documented outcrop zone for tens of kilometres around the southwestern syncline (Fig. 3). The apparently igneous protolith is altered to assemblages of epidote, hematite and quartz, and its nature is obscure except in a few localities where intrusive textures are preserved. Observed rock types range from ultramafic (phlogopite-feldspar rock), through intermediate (monzogabbro) to felsic (leucogranite), although the mineralogy may reflect alteration effects rather than primary 
magmatic compositions. Widespread hydrothermal breccia within the zone comprises angular fragments of altered rock cemented by quartz, epidote and hematite. A grab sample of breccia returned anomalous values of $\mathrm{Cu}, \mathrm{Ag}$, $\mathrm{Au}$ and hydrothermal indicators $\mathrm{Bi}$, $\mathrm{Se}$, and Te (Percival et al. 2015). The altered and brecciated rocks have low magnetic susceptibilities $(0.00001$ to 0.0003 $\mathrm{SI}$ ), in contrast to those of the surrounding magnetite-bearing siltstones (0.0005 to $0.027 \mathrm{SI})$. Based on its apparent stratabound nature, the zone is approximately $500 \mathrm{~m}$ thick and dips $35-45^{\circ}$ north as part of the southwestern Montresor syncline.

Early mapping suggested that the sedimentary rocks of the Montresor syncline were deposited unconformably on Archean basement prior to folding, although no unconformity was identified (Frisch 2000). Recent work indicates a complex structural architecture for the belt that involves D1 thrust imbrication, followed by regional metamorphism, D2 extensional detachment and ductile D3 shearing, with subsequent open folding (Percival et al. 2015).

\section{Data for geophysical modelling}

Multiple geophysical datasets were used in the interpretation process. The aeromagnetic data were acquired by the Geological Survey of Canada (GSC) at $400 \mathrm{~m}$ line spacing, at $323 \mathrm{~m}$ above the topographic surface and gridded to $100 \mathrm{~m}$ using minimum curvature (Miles and Oneschuk 2013). The flight lines were oriented at $315^{\circ}$, perpendicular to the strike of the Montresor belt. The residual total-field (RTF) aeromagnetic grid was reduced-to-pole (RTP) and used in further data reductions (Fig. 3). Following a regional-residual separation, RTP data were extracted along-line for use in the GM-SYS ${ }^{\mathrm{TM}} 2 \mathrm{D}$ forward magnetic modelling program.

Regional gravity data were acquired from the Canadian Geoscience Data Repository found at: 
http://gdr.agg.nrcan.gc.ca/gdrdap/dap/search-eng.php. The data were gridded to $2 \mathrm{~km}$ using minimum curvature.

Detailed ground gravity data were acquired using a CG-5 gravimeter in July 2014. Station spacing was $250 \mathrm{~m}$ and the data were tied to the Canadian Gravity Standardization Net through the Ookpik Hangar gravity base station in Baker Lake. Vertical and horizontal locations were determined through differential GPS and computed using GNSS solutions. The resulting elevation accuracy is better than $10 \mathrm{~cm}$ for all station locations. Corrections to the gravity data include latitude, elevation, Earth's tide, Free Air and a final Bouguer reduction using a density of $2.67 \mathrm{~g} / \mathrm{cc}$. A non-linear filter was computed on the ground gravity transect and was subtracted from the profile to calculate the residual signal (Keating and Pinet 2011). This removes the long wavelength basement signature identified on the regional gravity data (Fig. 2). Subsequent interpretation and 2D forward modelling was done using GM-SYS ${ }^{\mathrm{TM}}$, a software package that performs 2 or $23 / 4 \mathrm{D}$ forward modelling. 2D modelling assumes anomalies extend along strike infinitely in the y-direction, which is not necessarily reflective of the geological setting. The authors experimented with $23 / 4 \mathrm{D}$ modelling using both equal strike $( \pm 500 \mathrm{~m})$ and variable strike $(-100 \mathrm{~m},+500 \mathrm{~m})$ extension in the \pm y-direction and found this had no impact on the computed response of the modelled intrusive units.

Density and magnetic susceptibility constraints imposed on the units were derived from samples acquired by GSC personnel during the 1982 and 2014 field seasons (Table 1). Magnetic susceptibility was measured using a Terraplus KT-10 meter. Density was calculated using the standard Archimedes Principle Submersion method. Where sampling was limited, selection of rock property values was guided by the physical properties of comparable sequences (Tschirhart 2014). 


\section{Gravity}

\section{Regional gravity field}

Fig. 2 shows the regional gravity field in the Montresor region. The regional geology map allows for a more robust interpretation of the high resolution gravity transect and provides insight into the broader characteristics of the Bouguer field, including the background level that determines the relative amplitude of anomalies. Knowledge of the surface geology and inferences about the deeper crust can help differentiate between local and regional geological features and thus facilitate removal of the regional contribution from the high-resolution data in order to emphasize near-surface structures.

The shallow geological contributions to the gravity field can be deduced from an analysis of the geological maps (Frisch 2000; Jefferson et al. 2014). The most prominent high (H1, -43 mGal) is on the eastern margin of Fig. 2. H1 coincides with a granulite complex comprising three lithologic units divided on the basis of grain size and mafic content with densities ranging from $2.68-3.05 \mathrm{~g} / \mathrm{cc}$ (Fraser 1988). Diorite and gabbro in the third group of granulite rocks have densities of 2.77-3.05 g/cc (Fraser 1988) and could produce such an anomaly compared to surrounding background rock densities of $2.67 \mathrm{~g} / \mathrm{cc}$. Granulite has been mapped in outcrop in the northeast and southeastern corners of the map area (Berman et al. 2010). Thomas (2012) suggested that mafic granulite underlies neighbouring granitoid gneiss and is the source of the much broader $\mathrm{H} 1$ anomaly. $\mathrm{H} 2$ in the northeastern corner of the map also corresponds to granulite-facies rocks that may extend southerly to connect with those of $\mathrm{H} 1$.

A large amplitude gravity low, L1, underlies the centre-northeastern Amer Belt. It is considered to be a deep crustal feature that cannot be explained by surface geology. Tschirhart et 
al. (2013b) model a linear belt of Amer Group strata with comparable densities to the measured Archean background $(2.67 \mathrm{~g} / \mathrm{cc})$. The low is anomalous in that it cannot be attributed to the Amer Group strata that are essentially the same along strike from southwest to northeast across this low. It is also unlikely that the low is an artifact of the minimum curvature algorithm fitting a smooth surface to the surrounding data points $(-67.3$ to $-65.2 \mathrm{mGal})$ because it contains four data points and has several more intermediate-to-low points on its flanks. On the other hand a subtle single-point high, H5 (-55 mGal) located on the southeast flank of the northeast Amer belt may be caused by a shallow source. The gravity station was measured on Archean amphibolite and ultramafic rocks (Jefferson et al. 2015), and the single gravity measurement is consistent with the density of those surface rock types, however, as with any single point high the measurement must be treated with caution (Tschirhart et al. 2013b).

L2 is a broad low that extends north-south over Archean gneiss, quartz diorite, and monzonite (average density of $2.67 \mathrm{~g} / \mathrm{cc}$ ) and terminates in the south beneath a body of Nueltin granite (1.76 Ga; $2.63 \mathrm{~g} / \mathrm{cc}$; Jefferson et al. 2015; Tschirhart 2014). Several outliers of Ps3 are preserved within L2 and may also contribute to the low, although their preservation may be a coincidental result of down-dropping relative to the $\mathrm{H} 1$ granulite complexes. Within L2, three stations are measured on Ps2 dolostone that has an average density of $2.80 \mathrm{~g} / \mathrm{cc}$ (Tschirhart 2014). This unit is relatively thin (Jefferson et al. 2015), so the high density dolostone must not contribute significantly to the Bouguer anomaly. At the southern end of L2 Nueltin granite is mapped as a thin sheet (Jefferson et al. 2015) and may contribute little to the end of the L2 low, however a high resolution gravity transect collected by the first author in 2010 does not reveal a significant contrast between Nueltin granite and Archean basement (data available at: http://gdr.agg.nrcan.gc.ca/gdrdap/dap/search-eng.php). 
A weak gravity "ridge", denoted by $\mathrm{H} 4$, is located about $10 \mathrm{~km}$ east of the Chantrey Mylonite Zone (CMZ). Undifferentiated Archean gneiss, quartz diorite, and monzonite are mapped here. With an average density of $2.67 \mathrm{~g} / \mathrm{cc}$ these units would not produce a gravity high with respect to the average density of the surrounding rocks $(2.67 \mathrm{~g} / \mathrm{cc})$. The southwestern end of the ridge flanks low density $(2.61 \mathrm{~g} / \mathrm{cc})$ Snow Island Suite (SIS) granite. H4 is likely due to a denser, deeper feature not exposed at surface.

A north-south striking gravity "ridge" of narrower wavelength to H4 is labelled H3 on Fig. 2. This feature is the focus of this study. The northern end of the ridge (-54 mGal) is defined by a station on the Montresor hydrothermal breccia zone, where rocks of average density $(2.70$ $\mathrm{g} / \mathrm{cc}$ ) are exposed (Table 1), implying a dense source at depth. Owing to uncertainty caused by the coarse spacing of regional gravity stations, the anomaly could extend into the region north of the belt.

\section{Regional gravity modelling}

Nearby regional gravity stations were projected onto Profiles 1 and 2 (top panel - red dots on Figs. 4, 5) highlighting the limited number of points constraining the regional gravity modelling. The sparse station spacing can only resolve geological features wider than $25 \mathrm{~km}$. However, smaller bodies identified from previous geological maps (Jefferson et al. 2015) and modelling (Tschirhart 2014) have been included for illustrative purposes. This includes the Montresor and Amer metasedimentary sequences (Ps1, Ps2, Ps3) ranging from 3 to $10 \mathrm{~km}$ wide. These belts do not contribute significantly to the regional gravity field, but emphasize the scale of the regional geological features under consideration. 
A first-order feature of the regional gravity field and gravity $2 \mathrm{D}$ forward models is a strong positive anomaly over the granulite complex (H1) in the east. Using Fraser's (1988) density information, a value of $2.73 \mathrm{~g} / \mathrm{cc}$ for the granulite complex was chosen (cf. Thomas 2012). The density values of the remaining lithological units are found in Table 1 or published in Fraser (1988), Thomas (2012) and Tschirhart (2014). The locations of the gravity profiles are shown in Fig. 2.

Transecting the northeastern end of the Montresor belt, Profile 1 (Fig. 4) is dominated by a strong positive anomaly associated with the granulite complex (H1). The Amer Mylonite Zone (AMZ) is located on the northwestern flank of $\mathrm{H} 1$ and displays steeply dipping fabrics. Sporadic occurrences of Paleoproterozoic Ps1 orthoquartzite have been mapped along and north of the AMZ (Jefferson et al. 2015) and illustrated in the modelling (2.63 g/cc - Figs. 4, 5). Northwest of the AMZ, the depth to the top of the denser (granulite) body increases gradually to $\sim 9 \mathrm{~km}$ at the northwest end of the profile. The Montresor syncline, with an average density of $2.70 \mathrm{~g} / \mathrm{cc}$, is modelled as a simple open fold of Paleoproterozoic sedimentary rocks overlying a sheet of augen gneiss (AgtSIS) interpreted by Percival et al. (2015) as part of the 2.6 Ga SIS. The augen gneiss in turn overlies undifferentiated Archean mixed gneiss.

Profile 2 extends from the granulite complex in the east to Archean mixed gneiss in the west (Fig. 5). The dominant H1 anomaly corresponds to the exposed granulite complex. Toward the west, the profile crosses a subtle gravity trough under the AMZ, the $\mathrm{H} 3$ ridge, and the southwest end of the Montresor belt overlies the slope between H3 and L2. Assuming that the granulite mass defines the long wavelength gravity signal it implies that the upper surface of the granulite complex is located at increasingly greater depth toward the west, stepping down across 
mapped faults. Surface geological features do not appear to influence this long-wavelength gravity pattern.

Modelling of anomaly $\mathrm{H} 3$ requires a body with a density of $2.83 \mathrm{~g} / \mathrm{cc}$ at a depth of $7 \mathrm{~km}$. The anomaly cannot be produced using the granulite density $(2.73 \mathrm{~g} / \mathrm{cc})$. A value of 2.83-2.90 $\mathrm{g} / \mathrm{cc}$ is typical of sparse mafic intrusive rocks in the region and $2.83 \mathrm{~g} / \mathrm{cc}$ corresponds to the measured density of a fresh gabbro dike south of the Montresor breccia zone (Table 1). Toward the west, outliers of Paleoproterozoic strata overlie Archean basement gneiss. They are not reflected in the gravity profile because either they have insufficient density contrast with Archean basement, are much narrower than the gravity station spacing and/or are too thin to contribute significantly. The profile terminates in the west where a smaller linear mafic body is modelled at $8.7 \mathrm{~km}$ depth to explain the $\mathrm{H} 4$ ridge. Alternatively the $\mathrm{H} 4$ ridge could be caused by a major dip-slip offset along a splay of the dextral Chantrey Mylonite Zone (Jefferson et al. 2015).

Understanding the regional features of the gravity field allows the interpreter to systematically determine an appropriate regional field to be removed from the detailed transect. After an analysis of the regional gravity forward models, the authors opted to model the regional gravity field using a non-linear filter, effectively removing the effect of the deep, gently northwest-dipping upper surface of the granulite complex. The non-linear filtered data was subtracted from the high-resolution gravity transect prior to detailed 2D forward modelling.

\section{Detailed forward gravity model}

Following removal of the regional field from Profile 3, the observed gravity signature is dominated by three highs; h1, h2, h3 (Fig. 6), the largest of which (h2) has an amplitude of 1.00 
mGal. A series of polyhedral bodies with density values obtained from Table 1 were modified to get a best match between the observed and computed gravity fields (top panel - Fig. 6). Surficial constraints were derived from lithogical and structural outcrop observations (Percival et al, 2015). The highs of $\mathrm{h} 2$ and $\mathrm{h} 3$ are $\sim 1.5 \mathrm{~km}$ wide, and are present across 4 stations. The anomaly associated with $\mathrm{h} 1$ is broader $(\sim 2 \mathrm{~km})$, with a peak amplitude of $0.5 \mathrm{mGal}$. A central low, 11, ($0.4 \mathrm{mGal}$ ) separates $\mathrm{h} 1$ from $\mathrm{h} 2$ and h3. A much smaller amplitude anomaly (stations \# 28-31) separates h2 from h3, suggesting that the two anomalies are separate entities. All three highs fall within regional anomaly $\mathrm{H} 3$.

With respect to geology, the gravity profile crosses from northwest to southeast: 1) moderately northwest-dipping siltstones (Ps3, $2.68 \mathrm{~g} / \mathrm{cc})$ of the Montresor syncline; 2) a structurally concordant D2 detachment fault juxtaposing the weakly metamorphosed Ps3 units with the underlying Ps2 schist (Fig. 6 - white dashed line); 3) muscovite, biotite-rich schist in the amphibolite facies $(2.82 \mathrm{~g} / \mathrm{cc})$, thought to correspond to regional Ps2 units; 4) a moderately northwest-dipping D3 mylonite zone $(2.65 \mathrm{~g} / \mathrm{cc})$ with strong southwest-plunging lineation; and 5) granodioritic augen gneiss $(2.67 \mathrm{~g} / \mathrm{cc})$ of the SIS with consistent northwest-dipping foliation. North of Profile 3 three distinct intrusive units are locally preserved within the altered and brecciated zone: leucogranite, monzogabbro and a phlogopite-plagioclase ultramafic rock (Percival et al., 2015). The leucogranite has an average density of $2.62 \mathrm{~g} / \mathrm{cc}$, whereas the monzogabbro and ultramafic rock are much denser $(2.90 \mathrm{~g} / \mathrm{cc}$ and $2.86 \mathrm{~g} / \mathrm{cc}$, respectively) and would produce positive gravity anomalies if present in significant volumes.

Incorporating the above lithologic constraints, the results of the detailed modelling are shown in Fig. 6. At the northwestern end of the profile is the unit of gently-dipping siltstone of Ps3 (labelled 2.68). This unit structurally overlies a gently northwest-dipping sheet of denser, 
amphibolite-facies schist of Ps2 (labelled 2.82) up to $350 \mathrm{~m}$ thick. The schist is separated from underlying augen gneiss by a gently northwest-dipping mylonite zone coincident with the centre of gravity low 11 . Three intrusive bodies $(1,2$, and 3$)$ are modelled as steeply northwest-dipping sheets in the subsurface. The northwest dip was required to fit the observed gravity responses, and is consistent with observed regional dips to the northwest. The semi-horizontal contact separating the augen gneiss and mixed gneiss cannot be discriminated by gravity as the two units have similar ranges of density. Fig. 6 shows an arbitrary structural contact between augen gneiss and granitoids and undifferentiated gneiss located at the top of the intrusive suites. Near the eastern end of the profile (station \#'s 28-30), well separated from the Montresor belt, a schist outlier is modelled at $2.75 \mathrm{~g} / \mathrm{cc}$ based on a sample from the outcrop at station 28 (Fig. 6). This is supported by the observed gravity anomaly between $\mathrm{h} 2$ and h3, where a thin, higher density $(2.75 \mathrm{~g} / \mathrm{cc})$ body is required to fit the calculated field to the observed.

Mathematically, the positive gravity anomalies $\mathrm{h} 1, \mathrm{~h} 2$ and $\mathrm{h} 3$ can be explained by varying thickness of denser units within or overlying less dense units (i.e. varying thicknesses of amphibolite-facies schist within or overlying the augen gneiss). Geologically, however, the positive gravity anomalies are best explained by denser units at depth. As the schist structurally overlies the augen gneiss, it would not be presents as rafts within the gneiss. Furthermore, outcrop observations at h2 and h3 (station \#'s 24, 34, 35) record augen gneiss and there is only one sample of augen gneiss greater than $2.72 \mathrm{~g} / \mathrm{cc}$. The observed gravity anomaly cannot be fit using the measured densities of the augen gneiss. Amphibolite schist is mapped below h1, and while a large, isoclinal D1 synform similar to those present in the Amer belt (Tschirhart et al. 2013b) could produce a positive gravity anomaly, such folds have not been recorded elsewhere in the Montresor region. The geological setting and observations suggest that $\mathrm{h} 1, \mathrm{~h} 2$ and $\mathrm{h} 3$ 
correspond to deeper, denser bodies located below the gneiss, in agreement with our modelling. Considering potential igneous compositions capable of producing anomalies h1, h2 and h3, the observed mafic and ultramafic units north and south of Profile 3, with densities in the $2.83-2.90$ $\mathrm{g} / \mathrm{cc}$ range, are the best candidates. Model densities of 2.83- $2.86 \mathrm{~g} / \mathrm{cc}$ produce similar responses and $2.86 \mathrm{~g} / \mathrm{cc}$ produces the calculated field shown in Fig. 6 . A denser $(2.90 \mathrm{~g} / \mathrm{cc})$ value for bodies 1, 2 and 3 (Fig. 6) would produce thinner and/or deeper bodies. Six km south of the high resolution transect, regional Profile 2 (Fig. 5) models a dense mafic body at depth as the source of H3. The anomaly is visible on Fig. 2 broadening toward the Amer mylonite zone in the south. It does not appear to extend north of the Montresor belt. The near-surface bodies corresponding to h1, h2 and h3 occur above H3 (Fig. 5) and could represent parts of a ca. $2.83 \mathrm{~g} / \mathrm{cc}$ intrusion. It is also possible that the modelled igneous bodies represent the feeder system to the intrusive rock- breccia- hydrothermal alteration zone exposed in the southwestern Montresor belt. Additional detailed gravity transects may be able to test this hypothesis and possibly locate any dense non-magnetic bodies at depth.

\section{Magnetics}

\section{Source edge detection}

Source edge detection routines provide an additional utility to enhance short wavelength features in aeromagnetic imagery. Apparent susceptibility mapping offers a means to map the edges of source bodies and indirectly estimate their magnetic susceptibility. The calculation works on the assumption that a series of vertical, square-ended, uniformly magnetized prisms of infinite depth extent are responsible for producing the magnetic field (Silva and Hohmann 1984). 
As implemented within Geosoft geophysical software, the aeromagnetic data must be reduced-to-pole and downward- continued to the topographic surface prior to the apparent susceptibility calculation. The downward continuation algorithm is inherently unstable and creates artifacts in the resultant data (Pilkington and Roest 1992; Fig. 7a). By modifying the downward continuation procedure one can negate these effects in the production of apparent susceptibility images. The Taylor series expansion (1) has been used in aeromagnetic interpretation routines for over half a century (Evjen 1936; Pilkington and Roest 1992) and offers a more stable downward continuation platform by transforming the measured anomalies to a common surface, in this case topography. A $2^{\text {nd }}$ order Taylor Series expansion follows the expression:

$$
T(z)=T\left(z_{0}\right)+\frac{\partial T}{\partial z_{z_{0}}}\left(z-z_{0}\right)+\frac{\partial^{2} T}{\partial z^{2}} \frac{\left(z-z_{0}\right)^{2}}{2}
$$

where $T(z)$ represents the magnetic field at the new observation level $z$, and $\frac{\partial T}{\partial z}$ and $\frac{\partial^{2} T}{\partial z^{2}}$ are the first and second vertical derivatives of the observed magnetic field, evaluated at the original observation level $\mathrm{z}_{0}$. Taylor series downward continued data are then input into the apparent susceptibility calculation described by Silva and Hohmann (1984). Despite the aeromagnetic derivative products having undergone no additional filtering the resultant image (Fig. 7b) is free of the spurious short wavelength artificial anomalies plaguing the conventional technique (Fig. 7a).

It is important to note that the actual geometry of geological units in the study area is inconsistent with the fundamental assumptions of the apparent susceptibility calculation. The geological features are not vertical, square-ended, or of infinite extent. Furthermore, variable 
thicknesses of glacial overburden overlie much of the region and increase the distance from source to sensor. Apparent susceptibility values do not reflect measured susceptibility values (Fig. 7a vs Table 1). Using the knowledge generated from the regional gravity modelling and geological mapping (Frisch 2000), it is presumed the magnetic rock units are steeply dipping and extend $\sim 2000 \mathrm{~m}$ in depth. The calculated susceptibility values will be smaller than the actual and do not provide realistic susceptibilities for input to $2 \mathrm{D}$ forward modelling routines. A source with an infinite depth extent requires a smaller maximum susceptibility to reproduce the anomaly amplitude (Silva and Hohmann 1984). To overcome this limitation, a linear transform (2) was applied to the data encompassing the Montresor syncline. This function transforms a set of values, in this case the apparent susceptibilities, to a range within a designated interval in the form:

$$
X^{\prime}=a+b X
$$

Where $X^{\prime}$ is the transformed grid, $a$ is the additive component, $b$ is the multiplicative component and $X$ is the input grid. The practicality of this scaling was tested using a synthetic grid (Fig. 8b) computed from two vertically dipping tabular bodies located $200 \mathrm{~m}$ below the sensor with the dimensions $200 \mathrm{~m}$ thick, $500 \mathrm{~m}$ deep and a $4000 \mathrm{~m}$ strike length (Fig. 8a). The magnetic susceptibilities of the synthetic bodies are 0.05 SI (southeast) and 0.01 SI (northwest). Following a $200 \mathrm{~m}$ downward continuation using a Tayler series expansion on the unfiltered derivative grids, the apparent susceptibility grid was calculated (Fig. 8c). The range of apparent susceptibility values on this grid (Fig. 8c) is -0.0002 SI to 0.0011 SI (0.00016 SI northwest body, 0.001 SI southeast body) in disagreement with the known magnetic susceptibilities. To transform the calculated grid to "real world" susceptibilities, the $a$ and $b$ values are solved for using the two sets of minimum and maximum apparent magnetic susceptibility values, calculated (-0.0002, 
$0.0011)$ and known $(0,0.05)$ ( $X$ and $X^{\prime}$, respectively). The transformed susceptibility grid is then computed from the calculated apparent susceptibility grid, $a$, and $b$ values using simple grid math. The transformed susceptibility values, now ranging from $0 \mathrm{SI}-0.05 \mathrm{SI}$, are $0.01 \mathrm{SI}$ and $0.05 \mathrm{SI}$ at the centre of the sources (Fig. 8d). Towards the edges of the sources the transformed susceptibilities deviate from the actual values, but are still comparable (Fig. 8c). Additional complications arise if there are large variations in the depth extent of the magnetic units (Silva and Hohmann 1984) or if the bodies are gently dipping. However, provided there is a large range of measured susceptibilities, the bodies are of similar depth extent and are vertically dipping, the linear transform should compute geologically realistic susceptibility values over magnetic sources.

Susceptibility values for Ps1, Ps2 and Ps3 sequences range from 0.00001 SI to 0.027 SI, whereas the range for the Taylor series apparent susceptibility grid is -0.000943961 SI to 0.00043014 SI, three orders of magnitude smaller. A linear transform was performed on the Taylor series apparent susceptibility grid, shifting the range of apparent susceptibility values to that obtained for direct measurements, i.e. susceptibility values of 0.00001 SI to $0.027 \mathrm{SI}$. This new apparent susceptibility grid effectively maps areas of low and high susceptibility, provides realistic magnetic susceptibility values for input to $2 \mathrm{D}$ forward modelling routines, and identifies source edges that emphasize structural features such as faults and offsets within the Montresor belt and surrounding units (Fig. 3 vs Fig. 9b). Sample collection was restricted to the southern edge of the syncline (red dots on Fig. 9a), providing good control on the rock properties of southern limbs but poor control on the interior limbs. The transformation of the apparent susceptibility values complemented the $2 \mathrm{D}$ forward modelling of magnetic data as the 
transformed values could be designated to magnetic bodies where sampling was non-existent or limited.

To complement the edge analysis, a digital elevation model (DEM) was downloaded from the Canadian Digital Elevation Database (CDED) and included in the interpretation process. Additional lineaments can be located on the air photos and Landsat data, however the DEM was most useful as the sun-shading at different declinations highlights distinct orientations of fault systems. Sun-shading with declinations of $0^{\circ}$ and $270^{\circ}$ highlights east-west faults expressed in the topography and north-south structural features respectively. A comparison of topographic and magnetic features was made by overlaying a $60 \%$ transparent apparent susceptibility grid over the DEM grid. Whereas many structures are present on the DEM and apparent susceptibility images separately and do not coincide spatially, only large coincident features visible both topographically and magnetically were plotted. Many structures outside the Montresor belt proper were ignored during the interpretation process as they are not the focus of this modelling.

\section{Considerations}

The apparent susceptibility transformation method has additional complications if the geology is poorly known or there is limited sampling of magnetic units for physical property characterization. Where a magnetic unit is overlain by non-magnetic sources (glacial overburden, sedimentary sequences) the transformed susceptibility values as calculated will be smaller than the true susceptibility of the feature, as the distance to source is not compensated for in the Taylor series expansion. Distance to source will be distance of source to sensor + thickness of overburden. This transformation is further dependent on all magnetic units being exposed at 
surface. Buried magnetic units will have smaller transformed susceptibilities that do not reflect the susceptibility of the surface geology. Furthermore, potential complications with remanence are not addressed herein. However, when lithology and structure are known, and there is good control on the physical properties of the rock units, particularly the susceptibility of the most magnetic bodies in the study area, this method has utility to extract meaningful magnetic susceptibility values from the aeromagnetic data for forward modelling. By transforming the apparent susceptibility calculations to realistic values, a connection is established between the observed magnetic field and geology. This is applicable to the Montresor belt, where a range of magnetic susceptibilities is known, there is good control on the geology, and the magnetic sources are exposed on the limbs of the Montresor syncline.

\section{Magnetic interpretation}

Detailed magnetic susceptibility measurements within the hydrothermal breccia zone recorded low values associated with the altered breccia zone (Table 1). The average measured value is $0.00035 \mathrm{SI}$ and only one sample recorded a value $(0.00311 \mathrm{SI})$ above the average of all the collected samples. The alteration zone is semi-concordant between stratigraphically lower and higher magnetic siltstone units (Table 1). The magnetic units forming the elongate, concentric bulls-eye anomalies correspond to doubly plunging synclines (Frisch 2000) outlined by thin layers of siltstone containing disseminated magnetite, with magnetic susceptibility values up to $0.027 \mathrm{SI}$ in the Montresor belt (Fig. 9a). These compare to values of approximately 0.098 SI for similar siltstone units in the Amer Belt (Tschirhart 2014).

On the apparent susceptibility map a prominent negative anomaly characterizes the alteration and breccia zone over its observed $4 \mathrm{~km}$ strike length (blue polygon on Fig. 9b). This 
linear magnetic low can be traced over a strike length of at least $20 \mathrm{~km}$ along the southeast flank of the syncline toward the southwestern nose of the syncline (Fig. 9a). The low broadens where it wraps around the southwest nose of the syncline and extends northeastward for $20 \mathrm{~km}$ on the northwestern limb of the syncline. If metal enrichment is a consistent characteristic of the alteration zone, then this feature provides potential for low-grade, large tonnage mineralization similar to the Cripple Creek and other alkaline-related deposits of the southwestern United States (cf. Kelley and Ludington 2002).

Additional demagnetized zones suggest that zones of alteration and breccia may also be present along stratigraphically discordant (east-west) corridors. The southwestern syncline is transected by several east-west demagnetized zones compared to the northeastern syncline, where concentric ellipsoidal magnetic rings clearly outline that doubly plunging syncline (Fig. 9a). A north-south trending, wide non-magnetic zone separates the two synclines (Fig. 9a-1). Additional non-magnetic corridors appear to merge into this north-south zone. In contrast to the northeastern syncline, the central southwestern anomaly is transected by a series of $\sim 095^{\circ}, \sim 130^{\circ}$, and $\sim 000^{\circ}$ non-magnetic linear features that transect the magnetic units (Fig. 9b). The structures have also been identified as offsets on air photos and are visible on the DEM as linear topographic lows (Fig. 9b). The lineaments a, b, and c (Fig. 9b) trending $\sim 130^{\circ}$ are the most pronounced structures and can be traced by subtle ridges on the DEM with $0^{\circ}$ sun-shading. The lineaments appear as low susceptibility zones cross-cutting magnetic siltstone units on the apparent susceptibility image. No geological observations have been recorded on the $130^{\circ}$ lowmagnetic lineaments, so it is possible the demagnetization may be linked to altered zones that have not yet been mapped, or faults. Several of these structures intersect the previously mapped principal alteration zone (Fig. 9b), providing an additional linkage to the hydrothermal fluid flow 
hypothesis. Because these structures coincide with valleys filled by Quaternary materials, drilling across the features would be required to confirm if they are fault and/or alteration zones, as has been done in the area of the Aberdeen Sub-basin to the southwest (Tschirhart et al. 2013a).

Upon close examination of the apparent susceptibility grid, a set of subtle north-striking positive linear anomalies is visible south of the Montresor belt (Fig. 9a, 9b-pink lines). In this area, the augen gneiss is expressed on the apparent susceptibility map as linear $055^{\circ}$ striking bands, with alternating high and low magnetic susceptibilities of $\sim 0.055$ SI and $\sim 0.00016$ SI, respectively, that were recorded in outcrop and/or samples. The average magnetic susceptibility of the sampled mafic rocks is 0.0105 SI (Table 1), more magnetic than the augen gneiss values, but less magnetic than the high end of the range. Therefore, a moderately magnetic body underlying a sheet of augen gneiss could be expressed as a faint aeromagnetic high visible within the magnetic fabric related to the gneiss, as is observed in this area (Fig. 89). The north striking positive anomalies can be extended northward and correlated to the dense bodies modelled in Profile 3 (Fig. 6; white line on Fig. 9a, b) however the mafic bodies cannot be confidently forward modelled using magnetics across Profile 3 because of the over-arching signal of the Archean units. North within the Montresor belt, the high amplitude anomalies of the magnetic siltstone $(\mathrm{m} 1, \mathrm{~m} 2, \mathrm{~m} 3, \mathrm{~m} 4)$ mask any underlying signal that may be associated with additional moderately magnetic igneous bodies at depth. If additional mafic/ultramafic bodies were located within the central Montresor belt, they would not be apparent on the magnetic images. The most straightforward interpretation of the northerly trending linear magnetic anomalies is, however, that these are dykes of the Amer swarm as mapped by Jefferson et al. (2015) to the south and west of this area. 


\section{Magnetic modelling}

In light of the potential mineral prospectivity of the demagnetized, altered breccia zone, the nature and extent of that stratabound zone was examined through the use of magnetic forward modelling. Incorporating the above geological, structural, geophysical and petrophysical constraints, a profile transecting the syncline was extracted from the RTP aeromagnetic survey data. Four prominent magnetic highs are evident on the profile (m1, m2, m3 and $\mathrm{m} 4$; Fig. 10). The northwestern anomaly, $\mathrm{ml}$, is composed of two distinct peaks, visible on the apparent susceptibility image (Fig. 9a) as parallel $050^{\circ}$ lineaments on the northwest flank of the syncline. Anomaly $\mathrm{m} 3$ is similar in that it has two prominent peaks but these correspond to an inner magnetic ellipse. The apparent susceptibility grid (Fig. 9a) displays peaks $\mathrm{m} 2$ and $\mathrm{m} 4$ as two distinct lineaments, with $\mathrm{m} 4$ corresponding stratigraphically to $\mathrm{m} 1$ and trending $040^{\circ}$ on the northwest flank of the syncline, but the resolution of the RTP grid does not permit discrimination of the two peaks for either $\mathrm{m} 2$ (corresponding stratigraphically to $\mathrm{m} 3$ ) or $\mathrm{m} 4$ in Fig. 10. Magnetic lows 11 and 13 separate the two outermost highs $\mathrm{m} 1$ and $\mathrm{m} 4$ from the inner $\mathrm{m} 2$ and $\mathrm{m} 3$ highs, and a moderate low, 12 along the axis of the syncline, separates the interior peaks $\mathrm{m} 2$ and $\mathrm{m} 3$.

Two hypotheses were tested to examine the nature of the demagnetized altered breccia zone and its geophysically correlated linear magnetic lows: 1) the non-magnetic breccia zone is a folded stratabound unit within the host sedimentary stratigraphy, as suggested by its wrapping around the nose of the syncline; and 2) the non-magnetic breccia zone occurs along two vertical faults that intersect coincidentally in the southwestern nose of the syncline. An additional consideration is that given the hydrothermal magmatic nature of the altered breccia zone, this zone may either have developed before the Montresor Group was folded into the gentle syncline 
or its correspondence with the low-magnetic layer in the syncline is coincidental, in which case it may be restricted to just the zone where it has been recognized in outcrop. Non-magnetic mafic/ultramafic intrusions may intrude additional areas of the syncline, however they cannot be located without additional gravity data or field sampling. The best match for 11 was obtained using a vertically extensive non-magnetic ( $0 \mathrm{SI})$ body on the northwest side of the syncline, and for 13 on the southern limb, a northwest-dipping structurally concordant body (0.0003 SI). As the observed response of magnetic anomalies decreases with increasing depth it is possible that 1) the northern low-magnetic linear represents a much steeper dip of the stratigraphy along that limb, or 2) the demagnetized zone continues at depth below the limits of this model, possibly extending into the basement.

Interior units of the syncline were divided into a series of layers with varying susceptibilities in order to match the computed signal with the observed (Fig. 10). The magnetic susceptibility of each individual anomaly was allowed to vary only within the measured range (0.0001-0.027 SI; Table 1) and was guided by the calculated apparent susceptibility map (Fig. 9a). Structural measurements of outcrops influenced the modelled dip of the southeastern limb of the syncline, whereas less control was available in the north, where geological mapping is less detailed. Units on the southeast limb dip $30-45^{\circ}$, whereas dips as high as $75^{\circ}$ were recorded in the northwest and used in our model. Frisch (2000) estimated a thickness of $\sim 1800 \mathrm{~m}$ for the strata within the syncline, consistent with the modelled geometry ( 1700 m; Fig. 10).

\section{Discussion}

This study aimed to provide reconnaissance-level constraints on the geometry of the Montresor region based on integrated geological-geophysical modelling. As noted above, the 
geological history is notably more complex than previously recognized, including at least three generations of low-angle faults (Percival et al. 2015) that could have significantly displaced surface features from their subsurface extensions. Geochronology in progress will help to resolve the relative and absolute timing of events.

The regional significance of some of these structural events has not yet been established. Whereas the D1 (thrust) structures are also recognized in the Amer belt (Patterson 1982) and likely formed during a regional collisional event, the detachment (D2) structures may be related to a late-orogenic extensional phase of the Trans-Hudson orogeny. In this context the regional distribution of granulite-facies rocks may be relevant in defining metamorphic core complexes: characteristic features of some extended orogens. For example, the gentle northwesterly dip of the H1 granulite complex northwest of the Amer mylonite zone, based on the regional gravity profiles (Figs. 4, 5), is consistent with the geometry of core complexes in many younger orogens (e.g. Block and Royden 1990; Davis et al. 2002; Platt et al. 2014). Consequently, re-appraisal of the Amer mylonite zone may be warranted. Although prominent steeply-dipping structures indicate late transcurrent movement, earlier northwest-dipping detachment structures could also be present. Furthermore, depending on its timing, this extensional event could have been significant in the formation of basins hosting the ca. 1.85-1.70 Ga Dubawnt Supergroup, distributed in northeast-trending fault-bounded troughs (Rainbird et al. 2003), as has been demonstrated in the southern Basin and Range Province (Wagner and Johnson 2006).

The association of the mapped altered breccia zone with altered denser ultramafic to felsic intrusive rocks promotes ground gravity transects or airborne gravity gradiometry as excellent techniques for detailed follow-up. By focusing on fractured, low susceptibility areas in proximity to $\mathrm{H} 3$, detailed gravity surveys could identify dense zones within or beneath the 
Montresor belt as vectors to zones of breccia, hydrothermal alteration and potential mineralization. Conversely, traditional electromagnetic prospecting methods would likely not be an effective tool in light of the oxidized, sulphide-poor character of the hydrothermal zone.

\section{Conclusions}

The Montresor belt provides a case study where regional and high resolution gravity and magnetic data can be integrated with reconnaissance and focused detailed geology to test relationships between a hydrothermally altered breccia zone, mafic to felsic intrusions and linear aeromagnetic lows. In this study modelling of a detailed gravity profile defined north-trending mafic bodies at depth to the south of, and striking toward a hydrothermally altered breccia zone striking $050^{\circ}$. A novel method for transforming apparent susceptibility facilitates identification of linear negative aeromagnetic anomalies that are coincident with the breccia zone, and also apparently concordant with the stratigraphy that is folded into an open syncline. Forward magnetic modelling of the semi-concordant altered breccia zone is based on its very low measured and calculated susceptibility values and the apparent continuity of the associated linear aeromagnetic low for kilometres around the nose of the syncline, bracketed between double linear positive aeromagnetic highs generated by stratiform disseminated magnetite in siltstone. This structural continuity suggests additional prospective areas that have not yet been mapped on the ground. The apparent susceptibility image can be used as a guide to focus on areas with relatively low susceptibility and a possible high degree of fracturing. Detailed gravity surveys can also be used to locate dense bodies potentially related to intrusion-hosted and/or intrusiondriven hydrothermal alteration. This study illustrates the importance of integrated geophysical modelling approaches for analysing structures and alteration zones in remote regions with limited geological data. 


\section{Acknowledgements}

This is contribution 20140405 of Geological Survey of Canada as part of the Geomapping for Energy and Minerals - 2: Geology and Mineral Potential of the Chantrey-Thelon Area, Montresor Project. Logistical support was provided by Ookpik aviation and Polar Continental Shelf Project. Comments and reviews by M. Thomas, R. Smith, R. Enkin and an anonymous reviewer greatly improved the quality of the manuscript. 


\section{References}

Berman, R.G. 2010. Metamorphic map of the western Churchill Province, Canada. Geological Survey of Canada, Open File 5279, scale 1:2 500 000, 3 sheets +49 p. report.

Berman, R.G., Pehrsson, S., Davis, W.J., Ryan, J.J., Qui, H., and Ashton, K.E. 2013. The Arrowsmith orogeny: Geochronological and thermobarometric constraints on its extent and tectonic setting in the Rae craton, with implications for pre-Nuna supercontinent reconstruction. Precambrian Research 232: 44-69.Block. L. and Royden, L.H., 1990. Core complex geometries and regional scale flow in the lower crust. Tectonics 9: 557-567.

Davis, G.A., Darby, B.J., Yadong, Z., and Spell, T.L. 2002. Geometric and temporal evolution of an extensional detachment fault, Hohhot metamorphic core complex, Inner Mongolia, China.Geology 30: 1003-1006.

Evjen, H.M. 1936. The place of the vertical gradient in gravitational interpretation. Geophysics 1: $127-136$.

Fraser, J.A. 1988. Geology of the Woodburn Lake map area, District of Keewatin. Geological Survey of Canada, Paper 87-11.

Frisch, T. 2000. Precambrian geology of Ian Calder Lake, Cape Barclay, and part of Darby Lake map areas, south-central Nunavut. Geological Survey of Canada, Bulletin 542, 51 p. (2 sheets).

Frisch, T. and Patterson, J.G., 1983. Preliminary Account of the Geology of the Montresor River area, District of Keewatin. Geological Survey of Canada, Current Research, 83-1A: 103-108

Jefferson, C.W., Peterson, T., Tschirhart, V., Davis, W., Scott, J.M.J., Reid, K., et al. 2013. LIPs and Proterozoic uranium (U) deposits of the Canadian Shield; Geological Survey of Canada. Open File 7352, 56 pp + spread sheet, doi: 10.4095/292377.

Jefferson, C.W., Anand, A., Pehrsson, S.J., Peterson, T., Davis, W., Bridge, N., et al. 2014. Lithotectonic advances in the northeast Thelon Basin region - context for uranium exploration. Power Point presentation: Nunavut Mining Symposium, Iqaluit, April 10, 2014, http://www.nunavutminingsymposium.ca/presentations/.

Jefferson, C.W., White, J.C., Young, G.M., Patterson, J., Tschirhart, V., Calhoun, L., et al. 2015. Outcrop and remote predictive geology of the Amer Belt and basement beside and beneath the Aberdeen Sub-basin of the northeast Thelon Basin region, in parts of NTS 66A, B, C, F, G and H, Kivalliq Region, Nunavut. Geological Survey of Canada, Open File 7242.

Keating, P., Pinet, N. 2011. Use of non-linear filtering for the regional-residual separation of potential field data. Journal of Applied Geophysics, 73: 315-322. 
Kelley, K.D. and Ludington, S. 2002. Cripple Creek and other alkaline-related gold deposits in the southern Rocky Mountains, USA: influence of regional tectonics. Mineralium Deposita, 37: 38-60.

Miles, W. and Oneschuk, D. 2013. Northeastern Thelon - Garry Lake, NU, aeromagnetic compilation, parts of NTS 55, 65, 66 and 76, Nunavut. Geological Survey of Canada, Open File 7461, 2 sheets. doi:10.4095/292809.

Pehrsson, S.J., Berman, R.G., and Davis, W.J. 2013a. Paleoproterozoic orogenesis during Nuna aggregation: a case study of reworking of the Archean Rae craton, Woodburn Lake, Nunavut. Precambrian Research, 232: 167-188.

Pehrsson, S.J., Berman, R.G., Eglington, B., and Rainbird, R.H. 2013b. Two Neoarchean supercontinents revisited: The case for a Rae family of cratons. Precambrian Research, 232: 2743.

Percival, J.A., Tschirhart, V., Ford, A. and Dziawa, C. 2015. Report of field activities for the geology and mineral potential of the Chantrey-Thelon Area: GEM-2 Montresor Project.

Geological Survey of Canada, Open File 7707.

Pilkington, M. and Roest, W. 1992. Draping aeromagnetic data in areas of rugged topography. Journal of Applied Geophysics, 29: 135-142.

Platt, J.P., Behr, W.M. and Cooper, F.J. 2014. Metamorphic core complexes; windows into the mechanics and rheology of the crust. Journal of the Geological Society of London, doi 10.1144/jgs2014-036.

Rainbird, R.H., Hadlari, T., Aspler, L.B., Donaldson, J.A., LeCheminant, A.N. and Peterson, T.D., 2003. Sequence stratigraphy and evolution of the Paleoproterozoic intracontinental Baker Lake and Thelon basins, western Churchill Province, Nunavut, Canada. Precambrian Research, 125: $21-53$.

Rainbird, R.H., Davis, W. J., Pehrsson, S., Wodicka, N., Rayner, N. and Skulski, T. 2010. Early Paleoproterozoic supracrustal assemblages of the Rae domain, Nunavut, Canada: intracratonic basin development during supercontinent break-up and assembly. Precambrian Research, 181: 167-186.

Silva, J.B.C. and Hohmann, G.W. 1984. Airborne magnetic susceptibility mapping. Exploration Geophysics, 15: 1-13.

Thomas, M. 2012. Shallow crustal structure in the Meadowbank River - Tehek Lake area: Insights from gravity and magnetic modelling. Geological Survey of Canada, Open File 7308.

Tschirhart, V., Morris, W.A., Jefferson, C.W., 2013a. Faults affecting northeast Thelon Basin: improved basement constraints from source edge processing of aeromagnetic data; in Potter, E., 
Quirt, D., and Jefferson, C.W. (editors); Uranium in Canada: Geological Environments and Exploration Developments; Special Issue of Exploration and Mining Geology (CIM), Vol 21, 105-113.

Tschirhart, V., Morris, W.A., Jefferson, C.W., Keating, P., White, J.C. and Calhoun, L. 2013 b. 3D geophysical inversions of the north-east Amer Belt and their relationship to geologic structure. Geophysical Prospecting, 61: 547-560.

Tschirhart, V. 2014. Geophysical and geological integration and interpretation of the Northeast Thelon Basin, Nunavut. Unpublished PhD thesis, Department of Geography and Earth Sciences, McMaster University.

Wagner, F. H., III and Johnson, R.A. 2006. Coupled basin evolution and late-stage metamorphic core complex exhumation in the southern Basin and Range Province, southeastern Arizona.

Tectonophysics, 420: 141-160. 


\section{Tables}

Table 1: Physical rock properties.

\section{Figure Captions}

Figure 1: Context of the Montresor Group in the northwestern Canadian Shield after Jefferson et al., (2014). $\mathrm{AMZ}=$ Amer Mylonite Zone, $\mathrm{CMZ}=$ Chantrey Mylonite Zone, $\mathrm{STZ}=$ Snowbird Tectonic Zone.

Figure 2: Residual Bouguer gravity grid. Geological contacts after Jefferson et al., (2015) are traced as white lines and labelled; previous regional gravity stations are shown as black dots. Profile 1 and 2 are the locations of forwarding modelling of regional data. Profile 3 is the detailed ground gravity transect collected and modelled for this study. High (H1 to H4) and low (L1 to L2) gravity anomalies are labelled. Abbreviations are defined in the legend of Figure 4. $\mathrm{CMZ}=$ Chantrey Mylonite Zone, $\mathrm{AMZ}=$ Amer Mylonite Zone.

Figure 3: Residual high resolution total field (RTF) aeromagnetic data displayed over regional aeromagnetic data (north edge). Geological contacts extended from Jefferson et al., (2015) shown as white lines and labelled accordingly. Mapped low magnetic alteration zone is defined by arrows. SIS $=$ Snow Island Suite, Aagn $=$ undifferentiated Archean gneiss, AgtSIS $=$ augen gneiss and granitoid rocks, $\mathrm{AMZ}=$ Amer Mylonite Zone.

Figure 4: Forward gravity model across regional Profile 1. Top panel: black dots observed gravity, red dots regional gravity stations projected onto profile, red line calculated gravity, high (H) and low (L) gravity anomalies as labelled in Fig. 2. Bottom panel: geological cross-section, density values in $\mathrm{g} / \mathrm{cc}$ as labelled. 
Figure 5: Forward gravity model across regional Profile 2. Top panel: black dots observed gravity, red dots regional gravity stations projected onto profile, red line calculated gravity, high (H) and low (L) gravity anomalies as labelled in Fig. 2. Middle panel: geological cross-section, density values in $\mathrm{g} / \mathrm{cc}$ as labelled. Bottom panel: modelled cross-section displayed at natural scale (vertical exaggeration, $\mathrm{VE}=1$ ).

Figure 6: High resolution forward gravity model (location shown in Fig. 2) derived from Profile 3. Top panel: black dots $=$ observed gravity, red solid line $=$ calculated gravity, blue dots $=$ regional gravity data corresponding to right y-axis. High (h) gravity anomalies discussed in text. Bottom panel: geological cross-section, density values in g/cc as labelled, colour as in Fig. 5.

Figure 7a: Apparent susceptibility grid using downward continuation; b) apparent susceptibility grid using a Taylor series expansion and linear transform.

Figure 8a: 3D synthetic models of two tabular bodies displayed below the magnetic field grid; 8b) Observed magnetic field of synthetic bodies. Blue polygon outlines $0.01 \mathrm{SI}$ body and red polygon outlines 0.05 SI body; c) Calculated apparent susceptibility grid; d) Transformed apparent susceptibility grid. Ambient magnetic field parameters: $60000 \mathrm{nT}$, inclination: $90^{\circ}$, declination: $0^{\circ}$.

Figure 9a: Apparent susceptibility map of the Montresor Belt. Faults plotted as black lines, position of magnetic forward model (Fig. 9) plotted as white line. Frisch (2000) geological stations shown as yellow circles, Percival et al. (2015) geological stations shown as red circles. White line outlines inset map displayed in top left corner (8b); 8b) Apparent susceptibility at $60 \%$ transparency displayed over $0^{\circ}$ sun-shaded DEM. Alteration zone plotted as blue polygon 
on inset map, mafic and/or ultramafic anomalies outlined by pink lines. Black letters annotate faults discussed in text.

Figure 10: Magnetic forward model across Montresor syncline. Top panel: black dots = observed magnetic field, red solid line = calculated magnetic field. Magnetic $(\mathrm{m} 1-\mathrm{m} 4,11-13)$ anomalies are discussed in text. Bottom panel: geological cross-section, magnetic susceptibility values in SI as labelled, colour as in Fig. 5, with the exception of beige representing nonmagnetic siltstone $(\mathrm{SI}=0)$. 


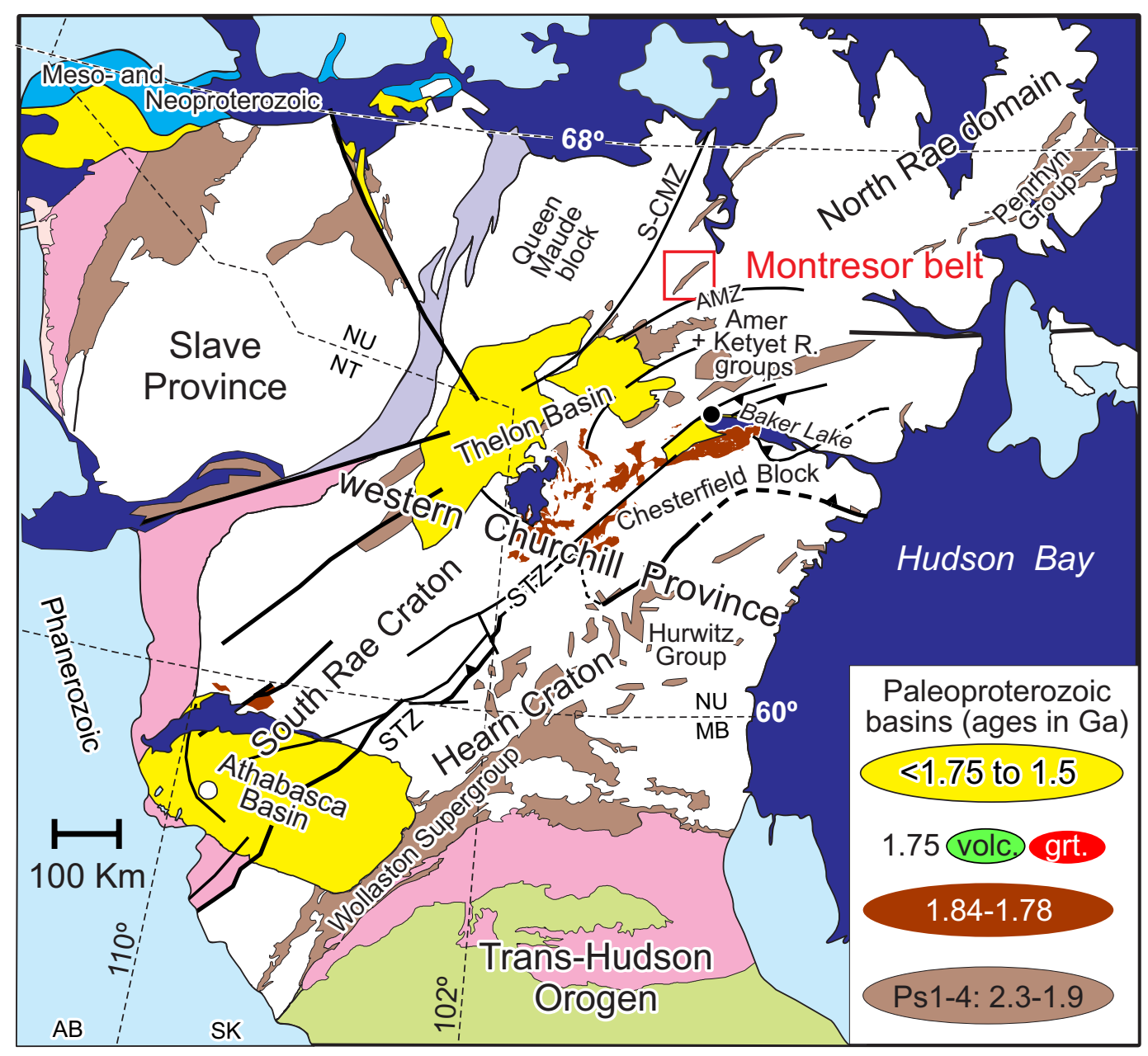




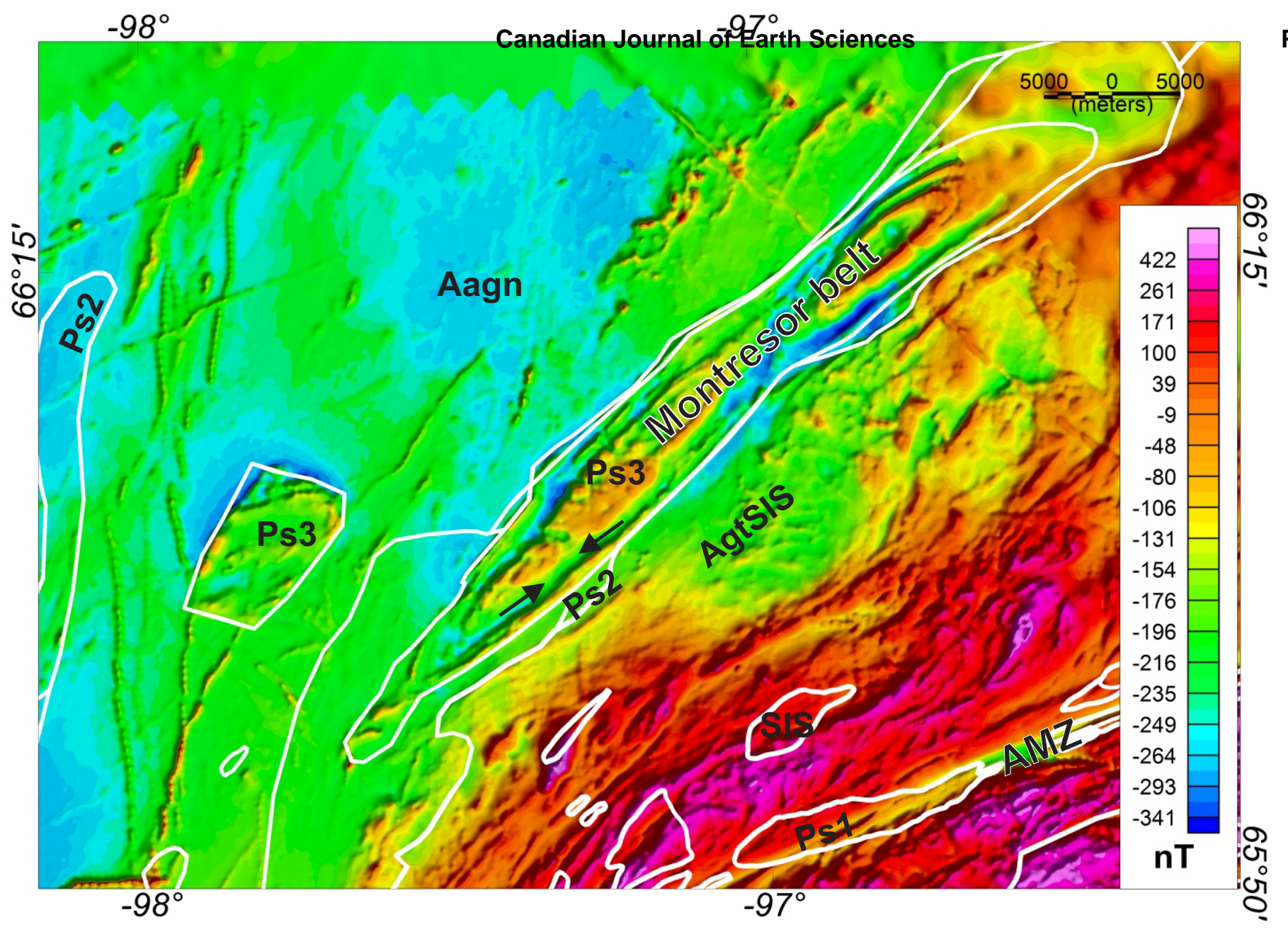

Page 36 of 44 

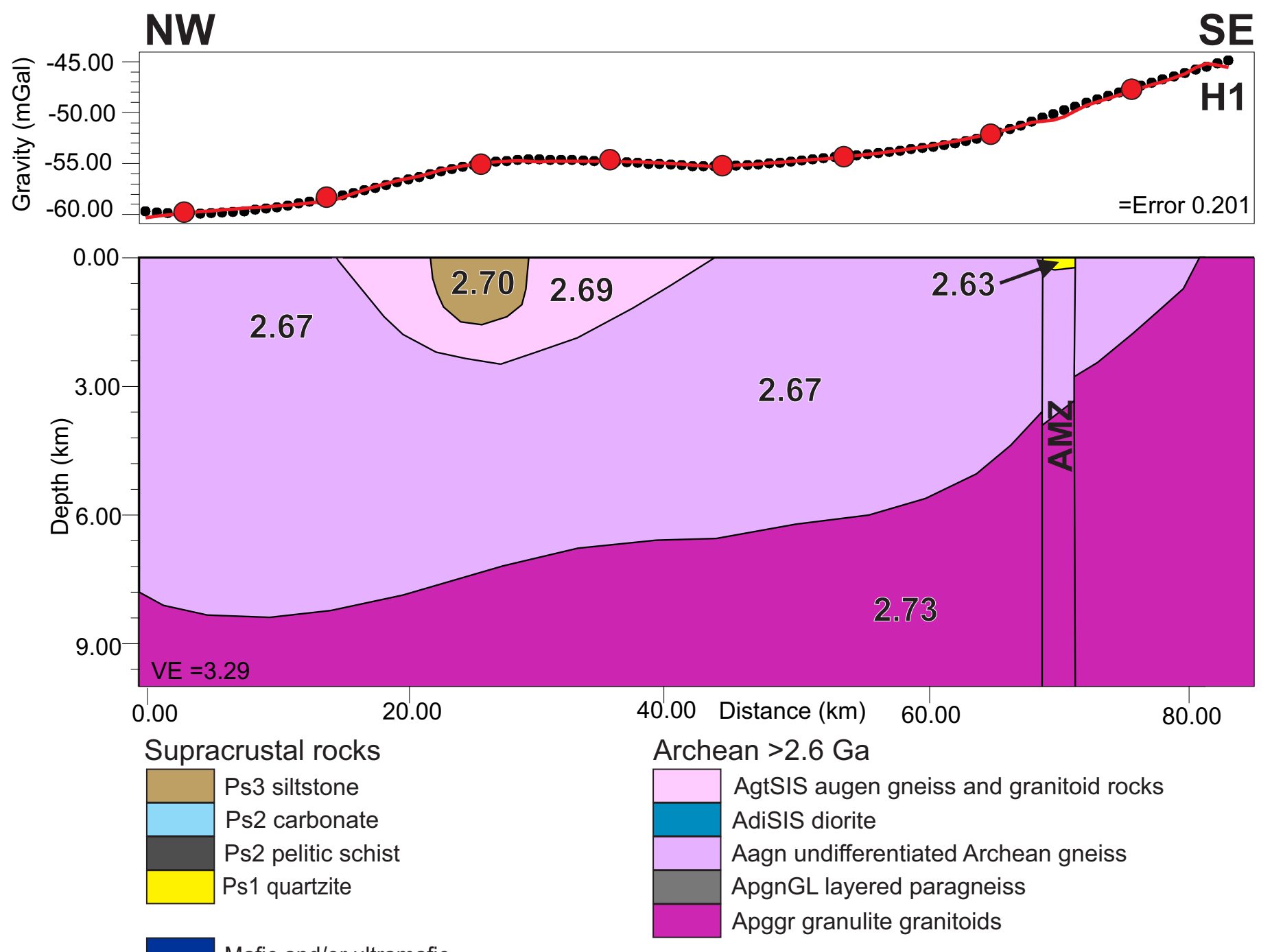


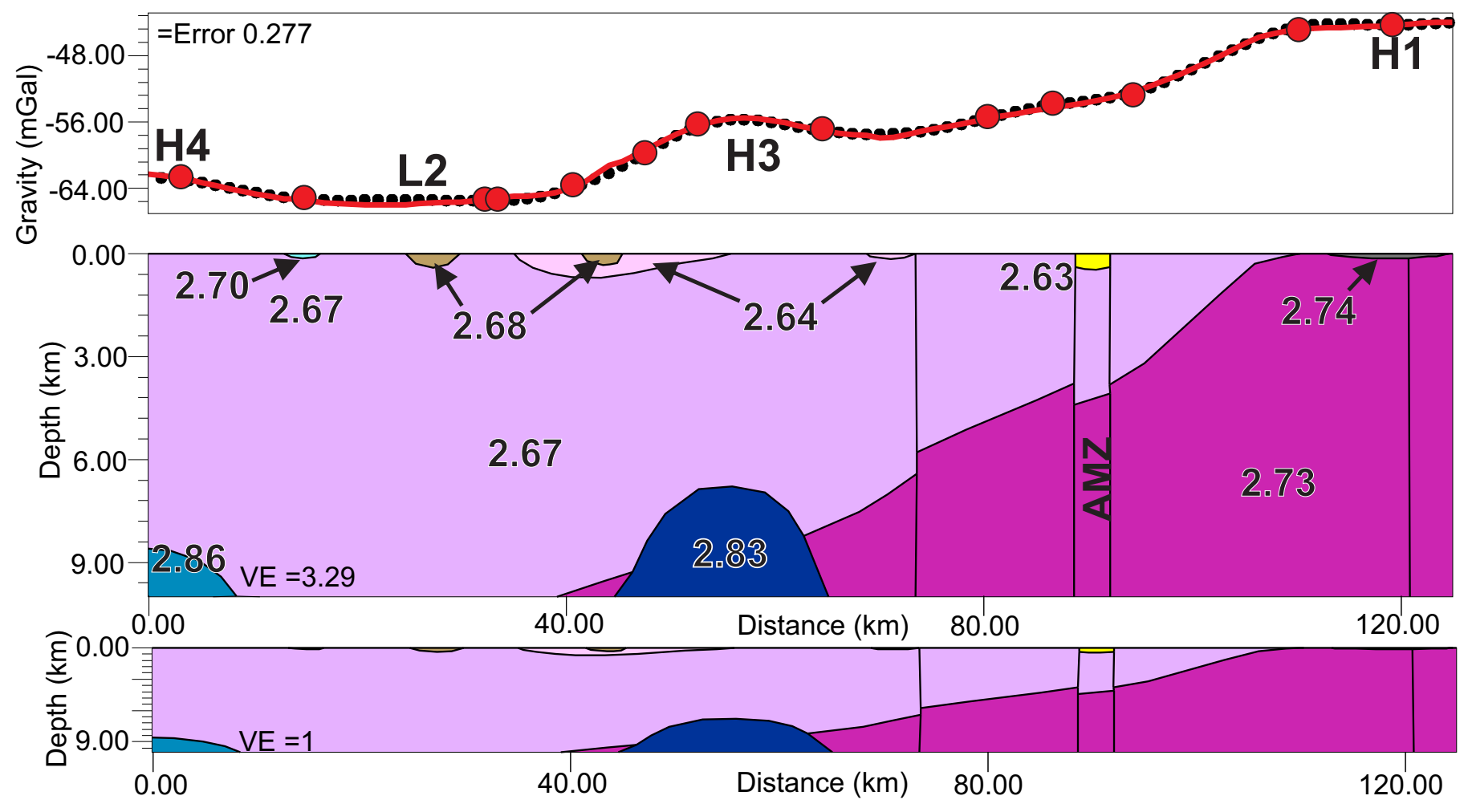




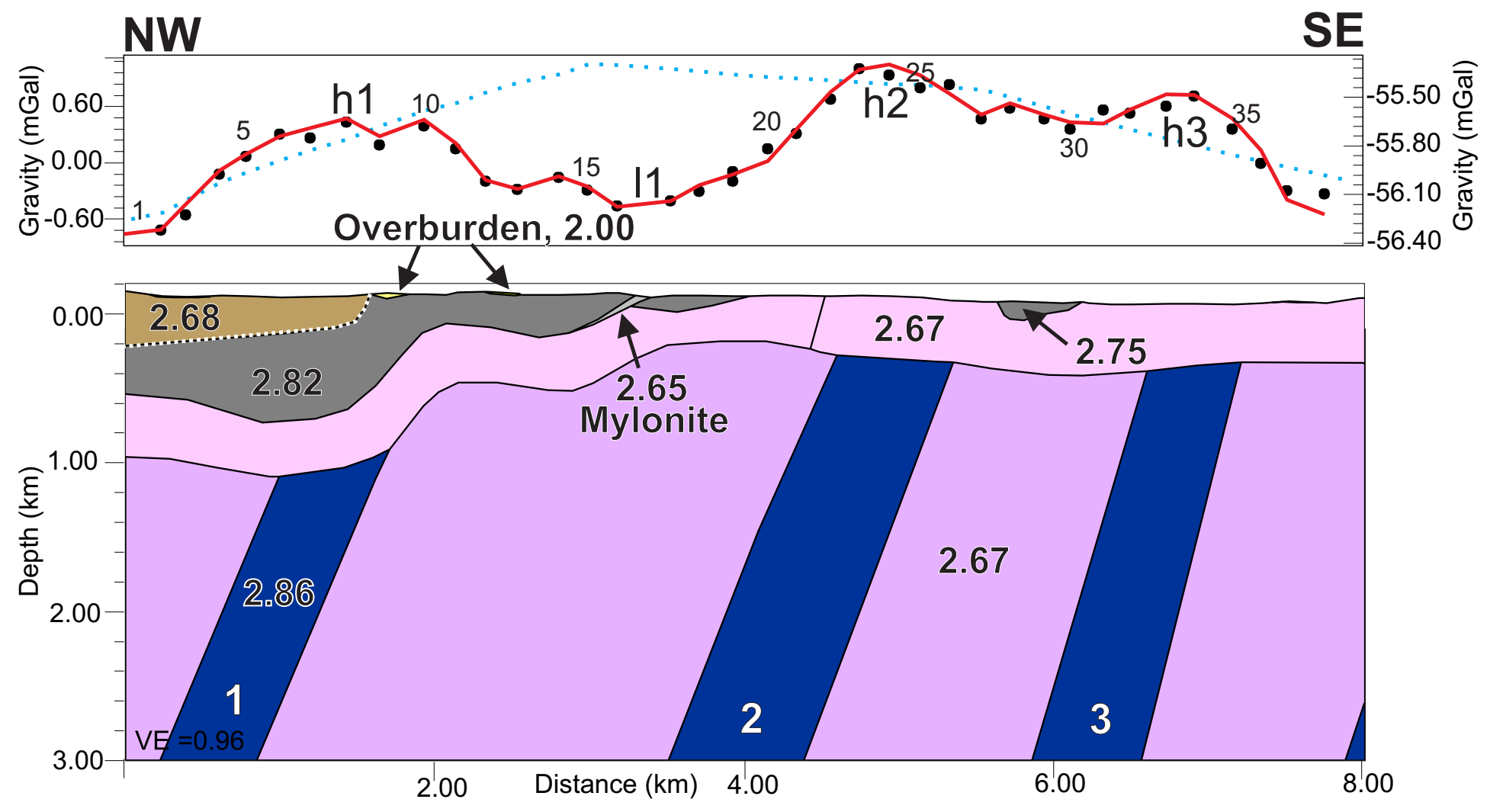




\section{Page 41 of 44}
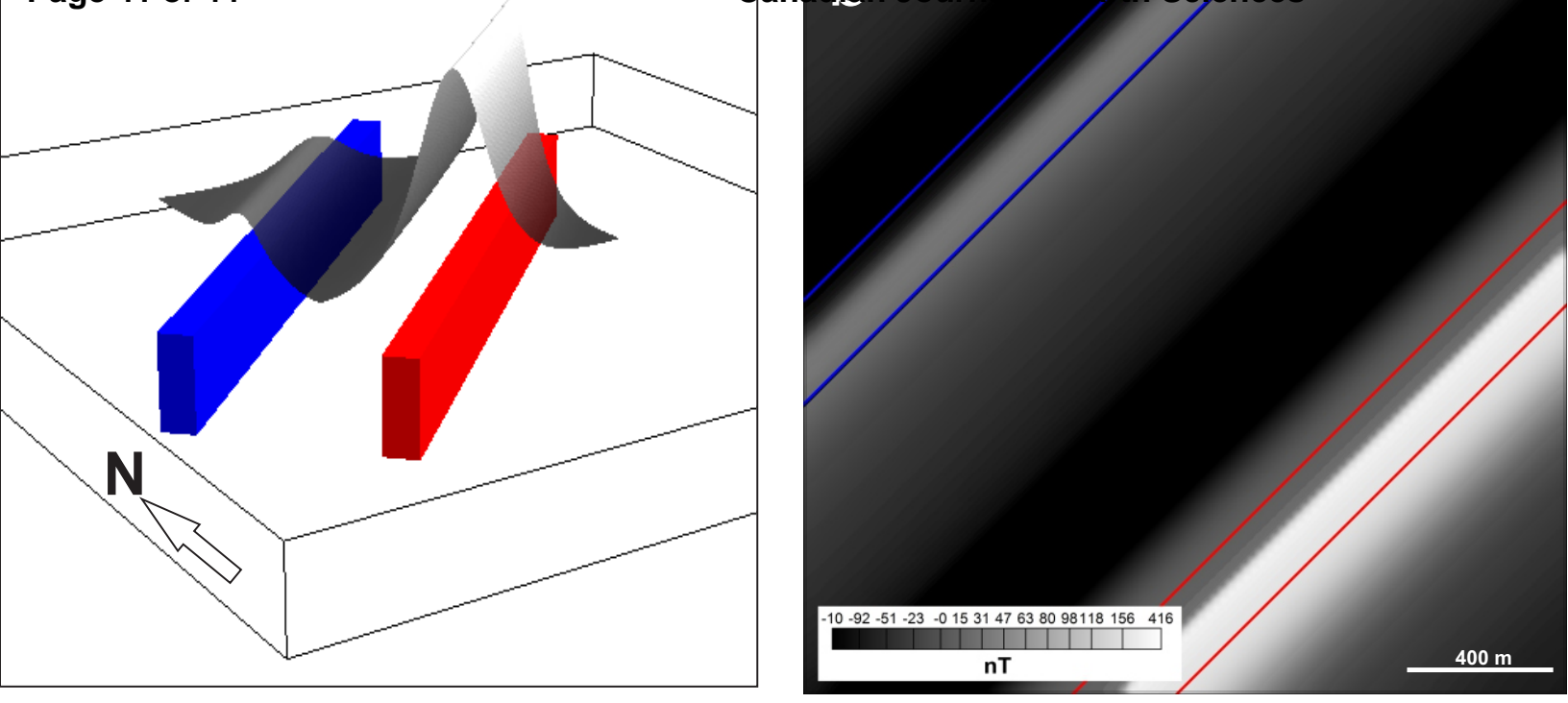

C

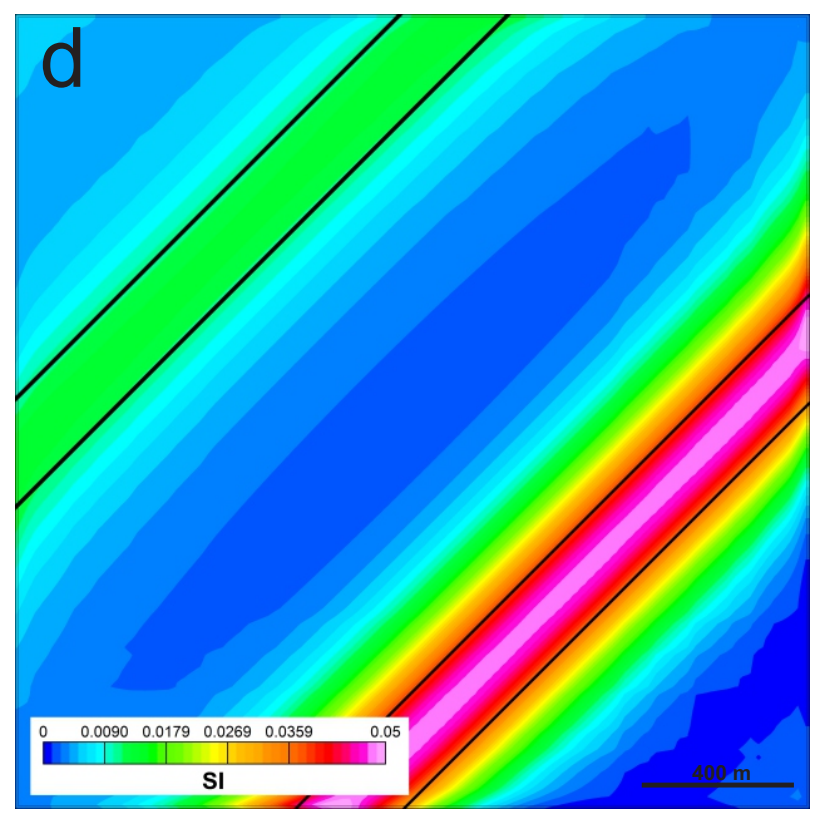




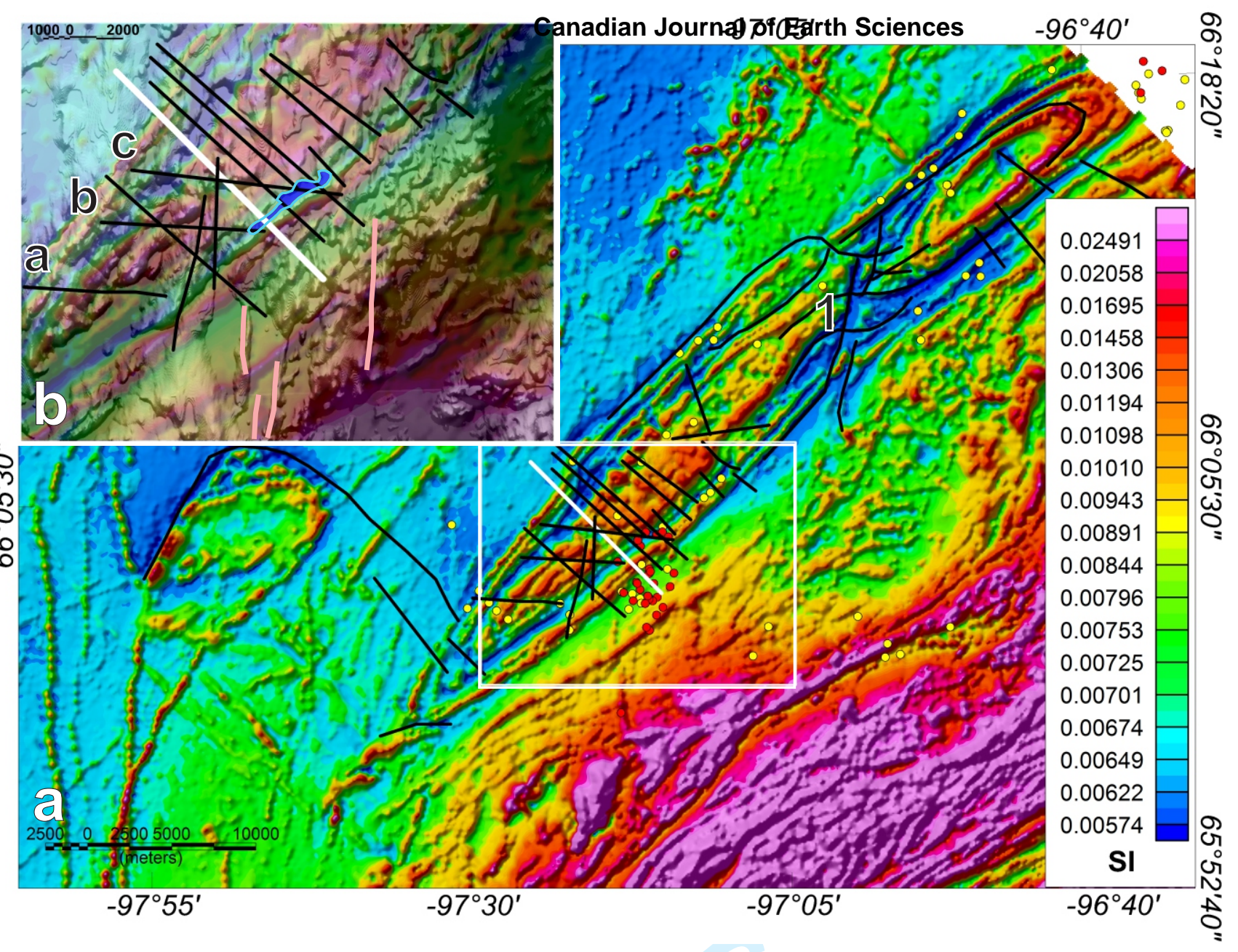

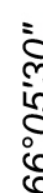



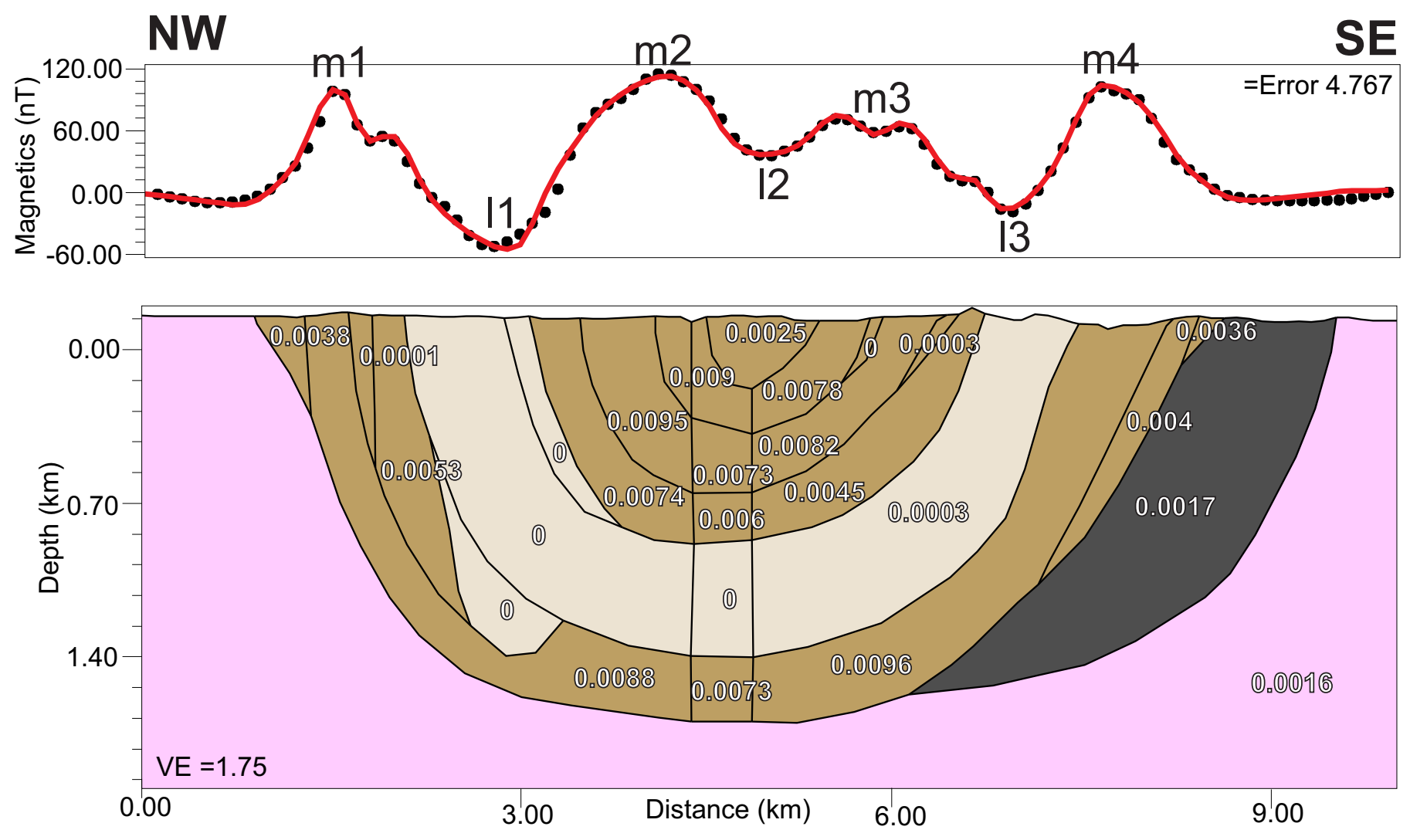


\begin{tabular}{|c|c|c|c|c|c|c|c|c|c|c|c|}
\hline Group & Map Unit & $\begin{array}{l}\text { Lithology } \\
\text { pegmatite }\end{array}$ & $\begin{array}{l}\text { Density } \\
\text { Avg. } \\
\text { (g/cc) } \\
2.62\end{array}$ & $\begin{array}{l}\text { Min. } \\
2.58\end{array}$ & $\begin{array}{l}\text { Max. } \\
2.64\end{array}$ & $\begin{array}{l}\text { St. Dev. } \\
0.025\end{array}$ & $\begin{array}{r}\text { Avg. Susc. } \\
\begin{array}{r}\left(\mathrm{SI} 10^{\wedge}-3\right) \\
0.042\end{array}\end{array}$ & $\begin{array}{l}\text { Min. } \\
0.000 \\
\end{array}$ & $\begin{array}{l}\text { Max. } \\
0.174 \\
\end{array}$ & $\begin{array}{l}\text { St. Dev. } \\
0.056 \\
\end{array}$ & $\begin{array}{r}n \\
4\end{array}$ \\
\hline Alteration Zone & & tectonic breccia & 2.75 & 2.65 & 2.82 & 0.061 & 0.350 & 0.055 & 3.111 & 1.000 & 5 \\
\hline Intrusive & & leucogranite & 2.62 & 2.61 & 2.63 & 0.009 & 0.030 & 0.000 & 0.100 & 0.043 & 2 \\
\hline \multirow[t]{3}{*}{ Suites } & & ultramafic & 2.86 & $\mathrm{n} / \mathrm{a}$ & $\mathrm{n} / \mathrm{a}$ & $\mathrm{n} / \mathrm{a}$ & 0.313 & 0.282 & 0.343 & $\mathrm{n} / \mathrm{a}$ & 1 \\
\hline & & monzogabbro & 2.90 & $\mathrm{n} / \mathrm{a}$ & $\mathrm{n} / \mathrm{a}$ & $\mathrm{n} / \mathrm{a}$ & 0.404 & 0.311 & 0.497 & $\mathrm{n} / \mathrm{a}$ & 1 \\
\hline & Dike & gabbro & 2.83 & $\mathrm{n} / \mathrm{a}$ & $\mathrm{n} / \mathrm{a}$ & $\mathrm{n} / \mathrm{a}$ & 67.427 & 62.74 & 72.37 & $\mathrm{n} / \mathrm{a}$ & 1 \\
\hline \multirow[t]{5}{*}{ Montresor Group } & Ps3 & siltstone & 2.70 & 2.54 & 2.86 & 0.073 & 2.954 & 0.000 & 26.990 & 5.693 & 61 \\
\hline & & sandstone & 2.67 & 2.60 & 2.82 & 0.066 & 0.881 & 0.000 & 14.570 & 2.353 & 35 \\
\hline & Ps2 & carbonate & 2.80 & 2.51 & 3.15 & 0.172 & 0.535 & 0.012 & 4.727 & 1.035 & 15 \\
\hline & & schist & 2.84 & 2.71 & 3.01 & 0.091 & 0.356 & 0.018 & 1.808 & 0.299 & 15 \\
\hline & Ps1 & quartzite & 2.67 & 2.60 & 2.82 & 0.050 & 0.985 & 0.000 & 20.570 & 3.185 & 31 \\
\hline \multicolumn{2}{|c|}{ Montresor-SIS contact } & mylonite & 2.65 & 2.64 & 2.65 & $\mathrm{n} / \mathrm{a}$ & 0.111 & 0.085 & 0.163 & 0.028 & 2 \\
\hline \multicolumn{12}{|c|}{ Snow Island Suite } \\
\hline \multirow[t]{3}{*}{$2.6 \mathrm{Ga}$} & SIS & augen gneiss & 2.69 & 2.62 & 2.75 & 0.037 & 2.282 & 0.000 & 19.090 & 3.769 & 18 \\
\hline & & augen granite, granitoid & & & & & & & & & \\
\hline & & rocks & 2.63 & 2.59 & 2.68 & 0.032 & 3.683 & 0.003 & 55.090 & 11.329 & 11 \\
\hline \multirow[t]{12}{*}{ Amer Group } & Ps4: Itza Lake fm. & arkosic sandstone $\&$ red & 2.66 & 2.49 & 2.80 & 0.075 & 0.086 & 0.000 & 0.292 & 0.077 & 57 \\
\hline & Ps3: Showing Lake fm. & mudstone \& siltstone & 2.66 & 2.57 & 2.76 & 0.069 & 6.348 & 0.055 & 15.130 & 0.726 & 8 \\
\hline & & sandstone & 2.74 & 2.45 & 2.95 & 0.110 & 0.337 & 0.011 & 5.540 & 1.164 & 22 \\
\hline & Ps3: Oora Lake fm. & feldspathic sandston & 2.64 & 2.48 & 2.78 & 0.101 & 0.444 & 0.033 & 0.966 & 0.378 & 8 \\
\hline & Ps3: Three Lakes fm. & grey mudstone and & 2.78 & 2.77 & 2.81 & 0.021 & 3.974 & 0.135 & 8.143 & 3.974 & 4 \\
\hline & Ps2: Five Mile L. basalt & porphyritic basalt & 2.88 & 2.68 & 3.06 & 0.091 & 9.818 & 0.112 & 54.617 & 16.204 & 21 \\
\hline & Ps2: Aluminum R. fm. & $\begin{array}{l}\text { siliceous dolostone } \\
\text { feldspathic sandstone; }\end{array}$ & & & & & & & & & \\
\hline & Ps2: Resort L. fm. $(<1.95$ & graphitic meta- & & & & & & & & & \\
\hline & Ga) & mudstone; siltstone & 2.74 & 2.48 & 3.09 & 0.114 & 0.175 & 3.000 & 7.226 & 1.640 & 19 \\
\hline & & schist, phyllite & 2.68 & 2.53 & 2.88 & 0.102 & 0.561 & 0.004 & 0.675 & 0.150 & 18 \\
\hline & Ps1: Ayagaaq L. fm. $(<<2.6$ & quartzite \& & & & & & & & & & \\
\hline & Ga) & conglomerate & 2.68 & 2.60 & 3.00 & 0.084 & 0.070 & 0.000 & 1.050 & 0.182 & 37 \\
\hline
\end{tabular}

